\title{
On historical consciousness and popular pasts
}

\author{
Kalle Pihlainen \\ kalle.pihlainen@abo.fi \\ Åbo Akademi University \\ Academy of Finland Research Fellow \\ Domkyrkotorget, 3 \\ 20500 - Turku \\ Finland
}

\begin{abstract}
This article investigates the nature of historical consciousness - conceptualizations and constructions of the past outside academic history - and the way in which this has changed in parallel with developments in historical theory in recent decades. With the increased constructivist questioning of historical narratives as somehow objectively true, academic history is seen to have lost some of its authority regarding the past. It is argued that, in becoming more aware of its nature as interpretation as well as more sensitive to its motives and consequences, history now has the potential to become more pragmatic and presentist. At the same time, some theoretical discussions have turned to the less strictly historical questions of memory and presence, thus evading the call to responsibility. By examining historical consciousness in relation to these debates, the article suggests that, in line with the liberation of the past from the constraints of academic history, historical consciousness no longer needs to be as focused on the interpretations and knowledge provided by the institution of history but can be increasingly determined by popular understandings and the needs of consumers.
\end{abstract}

Theory of history; Constructivism; Experience.

Received on: 8/26/2013

Approved on: 12/13/2013 
In what follows, I approach the question of the relationship between historical research and the use of the past by examining the idea of historical consciousness. Although historical consciousness offers a natural point of entry into this broader debate concerning the ways in which we relate to the past, it is a problematic concept at the outset because it ties our temporal structurings and orientation in the world to history - that is, to institutional interpretations of the past. Views about the nature of history have changed significantly in recent decades, yet these changes have so far been largely ignored in the discussion of historical consciousness.

\section{The problem of historical consciousness}

A more detailed analysis of the meaning of historical consciousness is needed because the concept is so often used to point to broader thinking about the past that runs alongside academic historical research and writing - it is comparable to concepts like "the practical past" (OAKESHOTT 1985) as well as "cultural" and "collective memory" (see, for example, HUYSSEN 2003; ASSMANN 2006). In addition to the fact that historical consciousness is misleading as a concept (if not indeed a complete misnomer), understandings regarding the significance of this kind of consciousness need to be rethought to better accommodate contemporary views of what history is.

The most obvious challenge comes from the general loss of authority of historical knowledge, or - thought of in another way - from the increased use and popularity of history and historical knowledge independently of practicing historians. It can be argued that, as an institution, history and historical interpretations no longer appear as incontestable to the wider audience as in the past, or, at least, that the representations historians present are not seen as scientific to the same extent as before. Because the truthfulness and authority of historical representations has been brought into question in this way, the broader public now has more opportunities for using the past in ways that are meaningful to them. In this sense, the past no longer belongs exclusively to historians even in terms of knowledge about it. Hence historical consciousness can no longer be controlled by historical research (if it ever could).

Questioning the scientific nature of historical research and the truth status of the stories historians produce does not mean that factual information about the past could not be gathered through historical research methods. Extreme simplifications and polemic arguments of this sort appear to be based on an inability to distinguish between historical research and historical writing. Although a clear demarcation of these "phases" in historians' practice is impossible, distinguishing between them between research and writing - is imperative in theoretical discussions if we desire to gain a better grip on the phenomenon of history.

The heuristic separation of the writing or representing phase - the construction of historical stories - from the study of the facts of the past and the particular skills and methodologies involved in that study even on the level of common conceptions of history well reflects the popularization of historical consciousness. Even though the image of the past which history produces, as 
well as the facts that it brings to our knowledge, still (to some extent) direct our views of the past and its impact on our present, our personal, significanceladen past is increasingly openly constructed on the basis of present-day needs and demands. In addition, because this is primarily a question of selection of perspective, this personal past in no way clashes or competes with institutional history writing - or no more, at least, than different historical points of view and research emphases within the institution do with each other. It has, in other words, become quite accepted that the same phenomenon (and hence largely the same set of facts) can be examined from completely differing perspectives and in diverse contexts.

This same change in attitudes - the acceptance of irony, to employ Hayden White's terminology - is also borne witness to by the expansion of the range of institutionally recognized historical approaches. Where history in the 1950s mostly still consisted of a methodologically closely regulated and source-critical study of events and great men, this kind of history constitutes only a narrow slice of contemporary approaches. Alongside this "traditional" history, and at times even supplanting it, we now have a variety of approaches offering "alternative" points of view. Of these, particularly central have become microhistory and "everyday history" (Al/tagsgeschichte), social history, women's history and cultural history, as well as a number of even more politically focused approaches (for instance feminist, postcolonial and queer histories), each of which has its own theoretical canon. Despite the reforms that these approaches have facilitated, they too are committed to the habitual understanding of historical knowing and the ideals of truth implied by historical research. Even they do not focus on historical consciousness in a broader sense - on perceptions of the past and the meanings they can have for us - but primarily on history, on institutionally approved stories about the past as well as the factual information relating to them.

History and historical writing cannot, then, usefully be taken as synonymous with historical consciousness. And the same applies to historical knowledge.

\section{Historical consciousness as practical and popular knowing}

Although historical consciousness is thus in many ways based on history and historical writing, albeit through many stages and processes, it is also influenced by more current social discourses, popular culture, oral traditions, and so forth. Thus historical consciousness is strongly shaped both by the needs and priorities of the present - which direct attention to specific aspects of the past - and by the traces of the past, both physical and ideological. ${ }^{1}$

Any categorizing and categorical definition of historical consciousness would probably prove impossible and is, in any event, pointless from the perspective of the present article. ${ }^{2}$ It is perhaps enough to note, then, that the question of

\footnotetext{
${ }^{1}$ Any such presence of the past can best (and without needless mystifications) be explained in terms of a "practical past", independent of historical studies (see OAKESHOTT 1985). This concept has recently been revived by Hayden White (see e.g. WHITE 2012).

2 In his Metahistory (1973), Hayden White has famously used the concept of historical consciousness in charting views about history held by various nineteenth-century historians. However, Metahistory has been criticized for some time now, even in White's own assessments of it, for its restrictive and formalistic theoretical
} 
the nature of historical consciousness is complex, and the answer - the reading - depends almost entirely on the selected perspective. On the other hand, even though historical consciousness (or at least consciousness of history) can vary greatly between individuals, ranging from complete ignorance and disinterest to obsessive contextualization and historicizing of all activities, it is certainly a substantial heuristic tool on the group or societal level (see e.g. DAVIES 2006). Hence, an important issue relating to historical consciousness is its relation to the use of the past and, by way of this, also to the social role of historical studies.

As a result of its shared and partly institutional nature, historical consciousness is also to some extent normative. In this sense too, no understanding of the past is - indeed cannot be - purely epistemological but, instead, each one always also reproduces and reconstitutes earlier values and ways of thinking. The same dynamics of repetition is unavoidable, of course, in all linguistic activity since we always employ agreed-upon or "given" meanings. From this necessary structural inertia also follows that perceptions of the past and any general historical consciousness do not change in any obvious relation to the new factual knowledge and "discoveries" that historical research produces. The fact that historical consciousness is in this way independent of and detached from the study of the past in terms of knowledge also underscores the parallel independence of its function from that of research and from the institution of history. Historical consciousness - if such an entity can be located - is thus not in any way obliged to follow interests that research could somehow dictate. That is to say: the relationship between these phenomena is quite permissive.

The relative independence of historical consciousness (and, in fact, also of historiography) as well as the associated emphasis on functionality and prevailing needs is rarely present in discussions of historical research. Perhaps to an extent precisely because of the lack of attention given to these, historians have in recent decades felt justified in blaming the relativism associated with postmodernism for the fragmentation and pluralization of historical consciousness and historicities. Such accusations completely ignore the broad range and nature of conceptions relating to the past, however, and instead assume that historical research holds a privileged position in society.

However, this kind of freeing of the past is not only a theoretical phenomenon, but also part of a change that has a wider social reach (see e.g. HUYSSEN 2003; COHEN 2005; cf. also AGNEW 2004; 2007; MUNSLOW 2010). Indeed, the fact that the past has more non-controlled and popular applications than those belonging to the institution of history is striking; especially so when we stop to consider the everydayness and relentless presence of talk about the past, a phenomenon not

framework. In recent decades, the most influential contribution to discussions of historical consciousness is to be found in the work of Jörn Rüsen. For him, historical consciousness is first and foremost a process of signification, which facilitates an orientation toward the future. Like so many others, he too notes the connection between historical consciousness and the narrative structuring of experiences (RÜSEN 2005, 2426). Rüsen's intentions appear to be largely taxonomic, however; he defines a range of categories of historical consciousness, depending on particular uses. In parallel discussions, John Lukacs $(1994,12-14)$ has linked historical consciousness to self-understanding and Jorma Kalela (2000) has attempted to reconcile the ideals of more conventional historical studies with the inevitability of social uses of history. 
unrelated to the (almost always) unavoidable need for thinking "historically". The consumption of the past in so many diverse ways is not - even in this "history" context - dependent on any scientific commitments to truth.

\section{Changing theory of history: the linguistic turn and ideals of objectivity}

Even though postmodern theorizing cannot be blamed for the instrumentalization and commodification of the past, the views it brings to the table are an integral part of this broader social change. In this sense, the debate within the theory of history and any consequent changes in attitudes help explain shifts in the status of historical research and in the contents of more general beliefs about history.

In the context of historical studies, postmodernism commonly refers to the linguistic turn and to the constructivist theorizing associated with it. The key figures in this contemporary form of constructivism include Hayden White, Frank Ankersmit, Keith Jenkins and Alun Munslow. ${ }^{3}$ The focus of these thinkers on the narrative nature of historical writing, as well as on the construction of meaning that takes place in narration, has led many historians to the extreme and erroneous conclusion that this narrative constructivism implies the equal fictionality or inventedness of history and literature. In other words, narrative constructivist theory is too often understood to argue that history is imaginary in the same way as fiction. Yet, approached more moderately - and more to the point - it should be clear that what is at stake is that the story constructed around historical facts is fictive because it does not and cannot as such (that is, as a story) have a counterpart in reality. What is important to understand, then, is that narrative constructivism is not premised on any anti-realism or even anti-referentialism - positions that would imply that reality did not exist or that history and historical writing could not somehow refer to it - and that it thus does not constitute a denial of historical study. Historical research retains its role of investigating the facts of the past, then, even after it becomes detached from the narrative construction of meaning (see esp. JENKINS 1999; MUNSLOW 2010).

Despite the self-evidence of the constructed nature of narratives, this kind of thinking has met with a great deal of resistance. Most objections appear to be based on insufficient reading or careless interpretations, however. When this so-called postmodern relativism is understood in its precise sense - as saying that meanings are not "out there" in the world but are constructed by readings - it does not seem to challenge commonsense intuitions or to significantly contradict our everyday negotiations of the world. Regardless, historians often experience it as contrary to the scientific aspirations of historical studies, at least with respect to the more traditional emphasis on methodology and objectivity. Yet we might optimistically think that some degree of relativism is a given for more recent trends in historical research; and, further, that the opposition to constructivism by proponents of these trends is based on the

\footnotetext{
${ }_{3}^{3}$ Their constructivism can be distinguished from earlier forms (constructivism à la Giambattista Vico, R. G. Collingwood or Michael Oakeshott, for example) by greater attention to narrativity - hence the designation "narrative constructivism".
} 
common misconception that constructivism also necessitates a disavowal of singular facts and the referentiality of historical representations. ${ }^{4}$

It may be that for a wider audience accepting these changes in theoretical thinking as well as in the various ways of approaching the past even within the institution of history is something much more straightforward. Claims concerning the scientific nature of history writing, for them, may indeed sound strange to begin with. For this public, stories are simply stories, and it has become quite comfortable - both through entertainment media and through serious news coverage, not least in the sphere of political opinion and political debates, I would say - with the idea that content can be, and often has to be, distinguished from opinions and interpretation. Contemporary reading sensibilities are often already ironic and have no room for the kind of objectivity that is still idealized in conservative views of history. ${ }^{5}$

\section{History as an engine of change?}

There exists an interesting paradox relating to the popular use of history and challenges to the authority of historical research: while conceptions about the past have been liberated from myths of straightforward interpretations and objectivity, expectations regarding the past and its significance have increased, or at least diversified. As consumers are now able to freely choose their own preferences, subjective positions and group affiliations, there is a different demand for evidence about the past and its impact. And while the subjectivity and ironic quality of such evidence and valuations is to some extent recognized, historical arguments still have a high status in many contexts. ${ }^{6}$ Hence, although the interpretation of the past is understood as being rhetorical on one level, this rhetoric continues to play a central role in the ways in which we position ourselves in the present.

Rhetoric based on views of the past is abundant, then, ${ }^{7}$ and it is often expedient to forget its heuristic nature when involved in the exercise of power. Of course, for this very reason, the ideological commitments of history and its important role in the strengthening of existing structures and institutions have been one focus of postmodern and poststructuralist theories. Consciously attaching this ironic awareness to broader interpretations and uses of history and the past - to historical consciousness - is of utmost importance.

\footnotetext{
${ }^{4}$ Many practitioners may experience talk of "traditional" or "objective" history as merely exaggerated or outdated rhetoric. When the constructivist aspect of history writing is emphasized, though, such rather extreme positions easily surface in reactions to it. Even in the theoretical debates about history there still exist views that seek to question the significance of the narrative dimension. The most blatant examples of these (and the ones that narrative constructivists have addressed in detail) can be found in e.g. IGGERS 2000 and ZAGORIN 1999. See also Ankersmit's detailed response to similar allegations on an earlier occasion, in ANKERSMIT 1990.

${ }^{5}$ On irony in White's thinking, see e.g. PAUL 2006. On irony and audience sensibilities, see PIHLAINEN 2008.

${ }^{6}$ As Christoph Classen and Wulf Kansteiner remind in their introduction to a very inspiring Theme Issue of History and Theory: "Most history products, be they novels, photographic exhibits, or docudramas, strive for a certain degree of factual accuracy; in this respect they take their cues from professional historiography. But the same products derive historical legitimacy, as well as entertainment value, primarily from a careful adaptation to and manipulation of contemporary media aesthetics. The real block-busters à la Vonnegut, Spielberg, and Friedländer appear to take considerable risks by committing well-gauged, yet radical, transgressions of the conventional limits of historical taste" (CLASSEN; KANSTEINER 2009, p. 3).

7 Martin Davies (2006) describes the pervasiveness of historical thinking with the apt term "historics".
} 
One possible way of emphasizing the practical and subjective nature of interpretations - while simultaneously leaving room for ideas about the past and its significance (and thus better engaging with the aforementioned paradox) - is to further underscore the formation of those ideas here and now as well as their specific and often intentional targeting of the present. As attention shifts to the purpose of particular interpretations, the question of the responsibilities involved in writing or representation also becomes better defined: historical research can be seen as having previously disregarded the question of its responsibilities by virtue of distorted views of objectivity - because what was said was simply "true". Thus the question of the consequences of representing was not relevant. Now, however, the issue of responsibility is increasingly determined on the basis of conceivable consequences: if the representation promises to serve the goals intended by the author, he or she has already actively assumed responsibility for the writing. While this may at first seem to provide cause for concern (which is why it has so often met with objections), there is no radical difference to earlier practice. In relation to historical consciousness, the idea of consequentialist or pragmatist interpretations is more natural: where particular facts do not entail specific stories or interpretations in historical writing, neither do the chosen stories or interpretations later entail specific attitudes and action when transferred to the level of historical consciousness. In other words, the ends to which interpretations are used, what is done after they have been presented, remains open and negotiable.

It can be argued that the practical and contractual nature of historical writing as negotiation is already evident in contemporary historical consciousness and the aware (if not necessarily ironic) uses we make of the past. If historical study has indeed lost its former authority over truth in the popular consciousness, then the evaluation of interpretations will have shifted increasingly toward pragmatic and aesthetic considerations there too. Since historical studies can no longer define and circumscribe acceptable interpretations or legislate the consequences of these, opportunities for social action and impact are now increasingly to be found in practical meanings and the form that representations take.

The consequences of readings and interpretations of the past, on the other hand, are determined on clearly pragmatic, extra-historical grounds. Because these consequences also come to be actualized - at least to a great extent - in the ways in which they shape the general historical consciousness and prevailing opinion, they cannot be assumed to be easily manageable from an institutional vantage point in the current intellectual climate. This is of course to be embraced, at least as long as we remember that contractual valuations and action - ethics and politics - are distinct from or independent of the knowledge produced by history. Again: there is no entailment from facts to values.

\section{Presentational form and vested interests}

Conventional history writing is sometimes claimed to uphold prevailing modes of thought and the hegemony of history simply by its employment of realistic representational forms. This is so, the argument goes, already simply 
because the illusion of unproblematic truth or congruent perspectives produced by realistic narration feeds into the idea of the existence of an objective history (or, once again, of an entailment from facts to values). As a result of the opportunities that realistic writing affords "objective" historying in covering up these representational problems, many of the representatives of constructivism - with Hayden White at the fore - have called for the adoption of alternative forms. Such forms would break specifically with that of the nineteenth-century realist novel, still most often taken to constitute the archetype for conventional history writing in these discussions.

White in particular has actively sought these alternatives from modernist literature and experimental art (WHITE 1978; 1999). This is more than understandable, since modernism in this literary sense focuses expressly on challenging the existence of unequivocal truth and on emphasizing the importance of subjective perspective. The possibilities of alternative presentational forms have, however, still received scarce attention within historical writing (for more on these, see e.g. PIHLAINEN 2002; 2009).

Partly from this same desire to subvert the realistic form of writing, a number of historians and theorists - White included - have turned to film as a potential source of inspiration for historical representations (WHITE 1999; see also e.g. MUNSLOW; ROSENSTONE 2004; HUGHES-WARRINGTON 2007). This option seems at times to involve, however, a conception of film as somehow a superior medium (and on occasions even an unproblematic one) in and of itself, and consequently the need for alternative narrative form is forgotten. When film is defended as a means of representation on the basis of its immediacy, its visuality, or its effectiveness in producing heightened experientiality, for example, the question of its form and the assumptions and values related to that form are often ignored.

In many discussions, comparisons between means of representation seem to me too easily to return to questions of content and facts, and the determining ideal of realistic form goes unchallenged. Even when attention is given to impact, focus is often on the experiential effect produced or on the power and credibility of the performance. In neither case is the problem of the possibilities of historical knowledge fully addressed on the level of the form or that of narration. Even though the discussion of the effectiveness of a representation already introduces a move away from the fact-fiction debate in the epistemic sense, at stake are still - at least in the case of popular, entertainment-oriented presentations - accustomed forms of narration; the limits and possibilities of representation are seldom investigated. In addition to film, this difficulty can be witnessed in the relatively conservative forms adopted even by many so-called alternative histories.

With respect to any general historical consciousness, the case is essentially identical. Historical writing, as well as the use of history and portrayals of the past in classrooms, films, historical novels, history villages, reconstructions, reenactments, and so on, still appear to be conceived of quite unproblematically - at least consumers are not actively reminded of the perspectival nature of representing the past (see e.g. AGNEW 2004). It might well be asked: why 
would it be a problem in the kind of already ironic and multiskeptical reception climate that I have described if there were no explicit connection (for consumers and for the institution of history alike) between representations and uses of the past and the idea of ambiguities, alternative readings and parallel perspectives? In practice this may well not constitute a problem. Consumers are increasingly skeptical and pragmatic and are not burdened by the same commitment to truthfulness as the historian. From the point of view of a theoretical discussion, as well as in considerations of mechanisms of power and control it might, however, be viewed as problematic that - despite the opportunities they offer - these more experimental forms of historical thinking also fail to foster skepticism.

\section{Historical consciousness and the freeing of the past}

The association of historical consciousness with conventional interpretive strategies and the availability of truth can, potentially, foster prejudice and narrow-mindedness. Transferred to practice, firm beliefs concerning the "true" state of things serve to complicate communication and exacerbate difficulties stemming from differences of opinion. Conversely, recognition of the unavailability of a meaning to the past may facilitate a more tolerant and open attitude both toward other people and toward their interpretations of the past and its impact on, for example, problems in their present. So, here too, historical research and facts have very little power: conflicts result from differences of opinion concerning meaning(s).

Historical consciousness is a misleading term precisely because it ties views about the past to history, to the institutional study and interpretation of the past. Although this conceptual difference is not obvious in everyday usage, and the role of historical research and writing as a component of historical consciousness is thus not explicitly determined, the terminology of the historical attaches us to a tradition of thinking in which historians have a somehow privileged take on and "access" to the past. Because history as an institution has the additional advantage of its hegemonic position and strong bonds with existing formations of power - history is still most often the interpretation of the past by those in power and it strengthens and reproduces conservative values -, harnessing it as an engine of historical consciousness produces conventional views that participate in obscuring and questioning marginal perspectives (again, it should be noted that this is not a statement about factual information, but about interpretations concerning the meaning of the past).

One might, of course, assume that such alternative approaches in historical studies, for instance microhistory or women's history, would provide the opportunity to counter the problems of a hegemonic history. Indeed, these once-radical positions have permitted some challenging of power structures within the institution of history. Today, however, they are largely part of that existing institutional structure. More importantly, because they have mainly been focused on new materials and subject points of view, they have not really deviated from the theoretical commitments of more conventional historical writing but have instead actively marginalized themselves with respect to 
the dominant interests in historical studies. To say it differently: since such approaches are usually interested in showing how existing research has neglected some aspect of reality, they too fail to inspire deeper investigation into the nature of historical writing and representation. Within the institution even these alternative approaches focus, then, on the search for a commensurable truth. Representational responsibility is thus not to the present but there is, instead, still a belief that it might somehow be possible (not to mention requisite) to "do justice" to the past. And as long as historical consciousness is thought of in this same fashion, it is hard to relate it to contemporary needs.

Distinguishing between memory, history and general views about the past is thus of paramount importance. When we realize that there is no direct or nonproblematic connection between history (institutional or institutionally sanctioned knowledge about the past) and discourses of memory or popular conceptions about the past (which undergo continuous change as a result of the varying contents, situations and demands of the present), historical consciousness is released from the requirements of veridicality ascribed to historical interpretation and narration. We can continue to hold pragmatically "correct" views about the ways and quality of life of people in the past, for example. But, on the level of such general historical consciousness, we will also understand that our views about the meaning of these conditions for those people do not constitute history or even contribute to the kind of knowledge that we can justifiably call historical.

\section{The pragmatic nature of views concerning the past}

Applied to historical writing, the dominant trend of constructivist theoretical thinking inexorably leads to presentism in the justification of interpretations. In other words, social and political conditions in the present come to play a significant role. Although dominant ideals of "objective" historying upheld for so long the view that bringing present-day demands and the situation of the author into talk about the past should be eradicated, such a requirement is of course impossible (as earlier forms of constructivism have similarly already reminded, of course). Historical studies necessarily involve representation and representation cannot be context-independent in this (or indeed in any) way. What is more, hiding behind illusions of objectivity and the empirical, as well as concealing one's subjectivity, is irresponsible on the part of the historian: for those historians who suggest that they are only reporting "things as they were" or permitting the past to "speak", this attitude merely provides a convenient excuse for not considering the consequences of their actions. And this, in itself, is sufficient to strengthen already existing prejudices. As White nicely expresses it: "Nothing is better suited to lead to a repetition of the past than a study of it that is either reverential or convincingly objective in the way that conventional historical studies tend to be" (WHITE 1987, p. 82).

If our views of the past were taken as being similarly entailed by facts, and in that sense free of interpretation, those views (or more emphatically: our historical consciousness) would be purely conformist. 
The pragmatic or presentist nature of historical consciousness, as well as of views about the past is, however, fairly self-evident and ineradicable. For this reason, the narrative constructivist challenge that has loomed over conventional history writing for so many decades does not constitute nearly as great a problem with respect to practical views about the past. Or is it possible to think about our views of the past as somehow detached from their significance - that is, from their function in identity formation and in the explanation and negotiation of existing states of affairs? As Jörn Rüsen (2005, p. 24) has noted: "Historical consciousness serves as a key orientational element [...]. Historical consciousness evokes the past as a mirror of experience within which life in the present is reflected".

According to a presentist way of thinking, the past has presence in our daily lives (albeit this should be qualified in many ways) and we may learn something from it, or at least construct something useful with reference to it. Yet, this does not amount to making the old claim that history can teach us lessons. Furthermore, it should be noted that in this kind of use of the past, historical studies are turned to largely in order to obtain bits of factual information as well as, perhaps, to find models and ways of thinking (stories, beliefs, values, ideologies, and so on) that are suited to our own very specific presentist needs.

During recent years, the idea of the presence of history and/or the past has resurfaced in history theoretical debates with great vigor. In contrast to the earlier discussion about memory, experiencing the past in some way directly and on a subjective level has now been one important object of enthusiasm. ${ }^{8}$ This latest interest may in part be a consequence of the fact that historical research no longer promises the same epistemological certainty and hence the resulting insecurities need to be addressed in new ways. A rather surprising champion of the idea of experience in the current debate has been Frank Ankersmit, especially with his Sublime Historical Experience (2005). The surprise here stems largely from the contradiction this advocacy of experience seems to establish with Ankersmit's previous narrative constructivist approach. ${ }^{9}$ Focus on the narrative or constructed dimension of history writing has now been displaced by the idea of a past that can be available and "present" without representation (see in particular ICKE 2011). ${ }^{10}$

As far as I can see, this line of thinking is motivated by a strong desire to demonstrate that the past has significance in the present, in other words, to show that the past and knowledge about it have a practical function.

\footnotetext{
${ }^{8}$ For a summary of the memory debate in the 1980 s and 1990s, see e.g. KLEIN 2000.

${ }^{9}$ For a concise presentation of his earlier position, see e.g. ANKERSMIT 1990.

${ }_{10}$ As Ankersmit notes $(2005,5)$, the reception of his arguments depends on what we make of the idea of "collective memory". As long as we discuss experience and the presence of the past on the level of memory and the individual, his claims are quite unproblematic. Things change, however, when this same terminology is taken up as a collective "remembering" and turned into the assertion that the historian can experience his or her community's past - a past beyond and outside of personal experiences - somehow "directly" (cf. ANKERSMIT 2005, 317 ff., esp. 337). Ankersmit makes comprehension of his position even more difficult by not making a clearer distinction between experience and the kinds of affects and heightened experientiality presented in his examples (most often, importantly, as a result of encounters with artworks).
} 
Particularly interesting about this discussion of presence is the way in which the concepts of memory (both individual memory and "collective memory" or remembrance on a social level) and history seem to have become confused (more on this in ICKE 2011). In this respect, the current debate goes much further than the previous one, which mostly centered on ideas of commemorating and respecting the past. In the debate of the 1980 s and 1990s, one interesting question was that of knowing and truth on the level of historical consciousness; monuments, for instance, were hoped to remind of the uniqueness of things and events in the past by striving for representation and metaphors that would prevent simplistic appropriations and closures regarding their objects (see e.g. YOUNG 2000). It was, in effect then, the same goal as that set by White when he argues for renewed forms of presentation in history writing. Ideally, written and cinematic representations, for example, could be held to lead to enhanced emotional effects and experientiality. In my reading, the goal (albeit still most often unarticulated, it seems to me) of the recent debate on presence has also been to bring experientiality to center stage. Yet, despite what I take to be at least a partially common goal, it is hard to understand suggestions that representation might somehow be bypassed and the past could produce experience "in itself" or be encountered "directly".

Even though the mystical emphasis of presence is also, in a sense, an argument about historical consciousness, it seems irrelevant to discussions about history and representing the past. This kind of presence - ultimately subjectively constructed and imagined - cannot help reintroduce epistemological or material foundations to contemporary debates. ${ }^{11}$

\section{The experientiality of the past}

The experientiality of historical writing has come to constitute an intriguing and often central issue in historical studies over the recent decades. It is also important for debates involving public history, the use and popularization of history, as well as historical consciousness. As already described, the question of experientiality has become more pressing following the loss of authority suffered by historical studies by a broader recognition of the epistemological problematics involved. Because history can no longer achieve sufficient credibility by appealing to the truth, it needs to be able to convince readers of the interpretations it provides by means of a strong experientiality or even simulated experiences. And, because history still predominantly exists in historical writing (or in representation by some other largely mimetic and most often narrative means), such experientiality is constructed primarily by means of form and associated aesthetic impact.

Broader historical consciousness is undoubtedly informed by these kinds of representational experiences as created by aesthetic means (heightened experientiality), but a major component is also the already discussed, faux

${ }_{11}$ For more on the tug of war between these perspectives, see e.g. RUNIA 2010; JENKINS 2010; and ICKE 2011. 
"experience" of the past: in encounters made possible by festivals, exhibits, museums, heritage sites and even memorials, for instance, viewers or participants may be significantly affected by the presence of preserved artifacts or by reconstructed conditions (they can be equally affected, of course, in more commonplace, everyday situations). At various kinds of heritage centers or history villages, events and reenactments, participants may also achieve much stronger experiences by an active engagement than they would as merely passive spectators (see e.g. AGNEW 2004; 2007).

Yet, it would be wrong to claim that such "experience" - seemingly encountering the past in these imaginary and completely mediated and constructed ways - could constitute some real or actual access to the past. On the other hand, these experienced encounters cannot be neatly returned to questions about history in the institutional sense or to knowledge about the past either. Importantly, then, while at stake is a parallel phenomenon to history, the concepts we use for tackling it should be distinguished from those we employ when dealing with historical studies. Having said that, there is some crucial common ground too. Historical studies and popular representations do share the same "imaginary" logic: beyond the factual or material dimension, they are both simply about interpretation, the employment of the imagination, illusion and fantasy.

But experientiality is a far more acceptable goal for popular representations that produce and reproduce views about the past than it is for historical 22 studies. This follows primarily from the simple fact that the history institution and its efforts to maintain a position of authority cause the difficulties in the first place. Because truth is so central to history's existence - at least in the current institutional manifestation -, it needs to defend its territory. But history has no comparable authority over popular interpretations - even if, it must be noted, historians do sometimes view the presentation of incorrect details and interpretations in films as something that requires their attention. This attitude might be justified if the function of these representations were still thought to follow from their contents. If, however, it is assumed that their function is not determined quite so straightforwardly (as would seem to be the case in light of present-day understandings), a greater role needs to be ascribed to the intentions behind and possible consequences of the representation. And if intentions and consequences are emphasized, both the truthful representation of individual facts and fidelity toward broader interpretations offered by historical studies become less important. A film may well incorporate invented materials (individual details are often not decisive for the meaning or "message" of a representation) or factual "mistakes" (after all, gaps in the existing data need to be supplemented just as they are in historical writing), and the interpretation it offers can be incompatible with those offered by historical studies (otherwise we could never have anything but conformist readings).

The genre commitments of film (as indeed the commitments of other forms of performance and art) require, rather, that it offer viewers something new and experiential, something that resonates with their reality (for more on this, see 
e.g. WHITE 1999; PIHLAINEN 2008; 2009; MUNSLOW; ROSENSTONE 2004; MUNSLOW 2010, esp. $182 \mathrm{ff}$.). This popular knowledge or general understanding of the past is not comparable to the knowledge produced by historical studies. Discussions focusing on the commensurability of these forms of knowledge are not meaningful, then, because the intentions of the practices in question are so far removed from each other.

Although the specific issues of the experientiality of historical writing and its reach and impact need to be further investigated, it is clear that popular forms of "history" are involved in the shaping of a broader historical consciousness and, even more visibly, in the entertainment of history consumers. Presentism and experientiality offer an opportunity to reach the audience more effectively, and factual considerations are set aside to achieve this.

\section{Conclusion: Historical consciousness as a practical tool}

In speaking of historical consciousness, it is important to understand the limited role of institutional historiography. This understanding requires some investigation into the nature of historical studies, as well as an acceptance of the constructed aspects of history. What should be realized, to put it succinctly, is that even though historical research can attain factual information about the past - and these facts can be effectively used in questioning narratives -, no necessity or entailment can be shown between that information or those facts and the story or meaning imposed on them.

The idea that facts do not entail a particular interpretation or narrative does not, however, imply the kind of extreme relativism that historians so often appear to expect and fear from constructivist theorizing. Facts will unavoidably play a role in the construction of historical narratives as long as the generic commitments of history require the use of the available information about the past. The significance of constructivism is in the idea that narratives do not exist in the past - and nor can they be found or discovered in factual information or with recourse to it. Put bluntly: if something does not exist, it cannot be found but must instead be invented (WHITE 1978, p. 82).

Similarly, and as long as we are talking about a specifically historical consciousness, it seems unreasonable to overlook the role of the institution completely. Historical studies have a part to play in shaping historical consciousness - especially as long as the attitudes and values it produces are systematically promoted in schools and by the media. Because institutional commitments largely continue to define contemporary forms of historical writing and representation on the basis knowledge - and there is no direct or unmediated way in which knowledge can be carried over into representations -, the institutional desire of history to act as guardian of the past is unreasonable. If the institution of history were to better recognize the role of interpretation and presentist intentions, its relation to historical consciousness would perhaps become less complicated too.

Likewise, arguments concerning the presence of the past are often overstated. The past cannot (already by definition) be present except by some 
means of representation: in this respect, constructivism appears extremely difficult to deny. Consequently all naïve, romantic or nostalgic thoughts about a "directly" or "innocently" available past and the lessons it can teach us in the present are equally problematic.

With respect to historical consciousness, the important issue is the function and purpose of the meanings that we attach to the past when speaking about it.

While such presentism has proven problematic in debates about historical studies, it does not seem to be nearly as controversial with regard to general thinking about the past or with respect to historical consciousness. Not surprisingly, contemporary consumers of the past are far more pragmatic in their daily lives than many professional historians are in their work. Indeed, it seems that the freedom afforded by popular historical consciousness for coping with uncertainty and making pragmatic interpretations in daily lives is only compromised by official history education and the popularization of the results of historical studies - at least as long as these latter forces choose to uphold the illusion of an epistemically sound and non-problematic relation between historical sources and interpretation.

\section{Bibliographical references}

AGNEW, Vanessa. Introduction: What is reenactment?. Criticism, v. 46, n. 3 p. 327-339, 2004.

24 - History's affective turn: historical reenactment and its work in the ANKERSMIT, F. R. [Historiography and postmodernism: reconsiderations]: Reply to professor Zagorin. History and Theory, v. 29, n. 3, p. 275-296, 1990.

. Sublime historical experience. Stanford: Stanford University Press, 2005.

ASSMANN, Jan. Religion and cultural memory: ten studies. Transl. Rodney Livingstone. Stanford: Stanford University Press, 2006.

CLASSEN, Christoph; KANSTEINER, Wulf. Truth and authenticity in contemporary historical culture: an introduction to Historical representation and historical truth. History and Theory, v. 48, n. 2, p. 1-4, 2009.

COHEN, Sande. Disparity, information, and consumption: hello to an agonistics of the future. In: COHEN, Sande; RUTSKY, R. L. (eds.). Consumption in an age of information. Oxford; New York: Berg Publishers, 2005, p. 155-180.

DAVIES, Martin. Historics: why history dominates contemporary society. London; New York: Routledge, 2006.

HUGHES-WARRINGTON, Marnie. History goes to the movies: studying history on film. London; New York: Routledge, 2007.

HUYSSEN, Andreas. Present pasts: urban palimpsests and the politics of 
memory. Stanford: Stanford University Press, 2003.

ICKE, Peter P. Frank Ankersmit's lost "historical" cause: a journey from language to experience. London; New York: Routledge, 2011.

IGGERS, Georg G. Historiography between scholarship and poetry: reflections on Hayden White's approach to historiography. Rethinking History, v. 4, n. 3, p. 373-390, 2000.

JENKINS, Keith. Why history? Ethics and postmodernity. London; New York: Routledge, 1999.

. Inventing the new from the old: from White's "tropics" to Vico's "topics" (Referee's report). Rethinking History, v. 14, n. 2, p. 243-248, 2010.

KALELA, Jorma. Historiantutkimus ja historia [Historical research and history]. Helsinki: Gaudeamus, 2000.

KLEIN, Kerwin Lee. On the emergence of memory in historical discourse. Representations, v. 69, n. 1, p. 127-150, 2000.

LUKACS, John. Historical consciousness: the remembered past. New Brunswick: Transaction Publishers, 1994.

MUNSLOW, Alun. The future of history. Basingstoke; New York: Palgrave Macmillan, 2010.

; ROSENSTONE, Robert A. (eds.). Experiments in rethinking history. London; New York: Routledge, 2004.

OAKESHOTT, Michael. Experience and its modes. Cambridge: Cambridge University Press, 1985 [1933].

PAUL, Herman. An ironic battle against irony: epistemological and ideological irony in Hayden White's philosophy of history, 1955-1973. In: KORHONEN, Kuisma (ed.). Tropes for the past: Hayden White and the history/ literature debate. Amsterdam: Rodopi, 2006, p. 35-44.

PIHLAINEN, Kalle. Of closure and convention: surpassing representation through performance and the referential. Rethinking History, v. 6, n. 2, p. 179200, 2002.

. History in the world: Hayden White and the consumer of history. Rethinking History, v. 12, n. 1, p. 23-39, 2008.

. On history as communication and constraint. Ideas in History, v. 4, n. 2, p. 63-90, 2009.

RUNIA, Eelco. Inventing the new from the old: from White's "tropics" to Vico's "topics". Rethinking History, v. 14, n. 2, p. 229-241, 2010.

RÜSEN, Jörn. History: narration, interpretation, orientation. New York: Berghahn Books, 2005.

WHITE, Hayden. Metahistory: the historical imagination in nineteenth-century Europe. Baltimore: Johns Hopkins University Press, 1973. 
Tropics of discourse: essays in cultural criticism. Baltimore: Johns Hopkins University Press, 1978.

. The content of the form: narrative discourse and historical representation. Baltimore: Johns Hopkins University Press, 1987.

- Figural realism: studies in the mimesis effect. Baltimore: Johns Hopkins University Press, 1999.

. Politics, history, and the practical past. Storia della Storiografia, $v$. 61, p. 127-134, 2012.

YOUNG, James E. At memory's edge: after-images of the Holocaust in contemporary art and architecture. New Haven: Yale University Press, 2000.

ZAGORIN, Perez. History, the referent, and narrative: reflections on postmodernism now. History and Theory, v. 38, n. 1, p. 1-24, 1999. 